\title{
Japanese women singer- songwriters of the 1970s: female agency, musical impact and social change
}

\author{
LASSE LEHTONEN \\ The University of Tokyo, Komaba, Tokyo, Japan \\ E-mail:lehtonen.lasse@gmail.com
}

\begin{abstract}
With the debuts of highly popular artists such as Matsutōya Yumi, Nakajima Miyuki and Takeuchi Mariya, Japanese popular music of the 1970s saw a rise of young female singer-songwriters. Not only were they notably successful commercially but they were also respected as creative artists. This recognition and valuation of female professional creativity was extraordinary from a gender point of view. Furthermore, their position as active social agents defied the social expectations for women in Japan at that time. In this respect, they can be conceptualised as a musical embodiment of the movements pursuing female emancipation in the 1970s. While the musical significance of these female singersongwriters has been recognised in previous studies, the gender point of view has remained largely unaddressed. By drawing from theories about female musicians and canon formation, this article re-assesses the social significance of Japanese female singer-songwriters of the 1970s.
\end{abstract}

Whether discussing production models, textual content or methods of audience participation and consumption, the period from the late 1960s to the late 1970s was a decade of turbulent change for Japanese popular music. Folk and rock of the late 1960s emerged from subversive political movements, and their negotiation of boundaries between authenticity and commercialism led to the discovery of alternative methods for music distribution outside the established record industry (Azami 2004, pp. 171-5). At the same time, the integration of rhythms and sounds of European and American popular music to the Japanese language signified a revolution in musical expression (Ogawa 1988, pp. 45-71; Satō 2019, pp. 187-226). This resulted in a considerable diversification of musical styles in mainstream pop music by the mid-1970s, when the originally subversive trends were harnessed as commodified products and their rebellious instigators became contributors to the music industry that they initially opposed as overly commercial. This development was fostered by the recognition of popular songs as 'legitimate culture' (Nagahara 2017, pp. 214-20) when Japanese society began to lean towards conformist middleclass society with values and tastes shared across the populace in the 1970s (Tsurumi 1984, pp. 108-38). The result - a fruitful convergence of different musical 
styles and modes of performance - was also a triumph for the music industry, which demonstrated success in commodifying even originally subversive trends.

This is a story that has already been told many times. ${ }^{1}$ As the account above demonstrates, its trajectory bears a striking resemblance to the changes typically described in histories of European and American popular music. It also represents an intriguing interplay between music and society as a narrative of a society becoming middle class through a process spurred by economic growth that tamed the 'noise' (as conceptualised by Jacques Attali) of originally subversive musical genres. However, as in historiography in general, this form of representation entails a risk of excessive focus on dominant discourses; consequently, this can result in (albeit often indirectly) defining other developments as minor or marginal (Frith 1996, pp. 15-6). This trend is most obvious in the case of subcultures but it extends even to what Kärjä (2006) calls 'mainstream canons'. For example, solely emphasising social and musical developments of an explicitly subversive nature means that those with more implicit undertones go easily unnoticed as potential social change.

An example worthy of attention is the rise of female singer-songwriters in the 1970s. Following the successful debut albums of Itsuwa Mayumi (b. 1951) in 1972 and Yuming (Arai/Matsutōya Yumi, b. 1954) in 1973, the 1970s saw the emergence of dozens of young women who both wrote and performed their songs, including Nakajima Miyuki (b. 1952), Takeuchi Mariya (b. 1955), Yano Akiko (b. 1955) and Yagami Junko (b. 1958). ${ }^{2}$ To be sure, there was nothing strikingly subversive about them on the surface; they typically did not write lyrics addressing political issues, nor did they claim to construct their authenticity based on anti-commercialism. Consequently, popular music historiography tends to focus on their extraordinary position in the music market as artists who were able to bridge the gap between commercial appeal and artistic quality. While this aspect is indeed worth noticing, it is the recognition of artistic quality itself that should attract more attention. After all, music histories tend to represent a masculine story that typically allows recognition of only a few female musicians (Reitsamer 2018, p. 27; Leonard 2007, pp. 26-30). Japan is no exception. When examined from this viewpoint, the emergence of female singer-songwriters appears as an extraordinary phenomenon with important musical and social implications.

The aim of this essay is to recognise these implications by discerning these female singer-songwriters from a gendered point of view. Such a task could obviously be approached from a variety of perspectives but I intend to focus on their position in music production, the media and historiography from a macro-level vantage point. I readily admit that this approach has its limitations; after all, this emphasis can easily neglect the importance of textual analysis (including the use of body and voice), music's role in everyday life and the importance of aesthetic experience (DeNora 2004). I believe, however, that these different approaches are complementary rather than separate lines

${ }^{1}$ For accounts on this process in popular histories, see Take (1999), Cope (2007) and Kikuchi (2008). Scholarly assessments on its various aspects ranging from music analysis to sociological viewpoints include Ogawa (1988), Minamida (2001), Azami (2004), Stevens (2008), Bourdaghs (2012), Nagahara (2017) and Satō (2019).

2 Names are given here in the Japanese order, that is, family name first. Before getting married in 1976, Matsutōya Yumi was known by her maiden name Arai but in Japan, she is most typically referred to by her artist name Yuming. To not make things overly complicated, I shall refer to her as Yuming excluding citations that use some other name. For an introduction to the careers of tens of female singer-songwriters who debuted in the 1970s, see Nagai (2013). 
of interpretation. Therefore, I want to consider this article as the first necessary step towards understanding Japanese female singer-songwriters of the 1970s as a phenomenon - one that will facilitate more detailed analysis of other aspects in the future.

From here on, I will refer to the musicians I study as 'female singer-songwriters' instead of using the more exhausting term, 'Japanese female singer-songwriters of the 1970s', but will naturally distinguish among them when necessary. 'Female singer-songwriters' do not, of course, constitute a genre: 'we can't talk about women as ... a subgroup of humanity that speaks with one voice' (Greig 1997, p. 168). Discussing female musicians as a uniform group entails a risk of suggesting female otherness and can end up both implying inferiority to men's music and reifying its supposed 'neutrality'. McClary (2002, p. 19), for example, remarks that many women composers 'insist on making their gender identities a nonissue' precisely for this reason. Nevertheless, there are contexts in which discussing female musicians as a group is reasonable. As I shall emphasise in this essay, female singer-songwriters bore significance in both musical and social spheres by constituting a category distinguishable from previous female and male musicians. Therefore, they should be discussed together (cf. Kutulas 2010; Lankford 2010; Nagai 2013).

Academic study of Japanese popular music has remained relatively marginal outside Japan but there are at least three reasons why these female singersongwriters should be of transnational interest. First, obvious parallels with such female musicians as Carole King and Joni Mitchell position Japanese singersongwriters as a part of an international continuum. Second, they provide one angle to the question of how women have negotiated their positions as creative musicians in different socio-cultural surroundings. Third, although Japanese popular music is primarily aimed at the domestic market, some of the female singersongwriters have also appeared in international contexts. For example, Miyazaki Hayao has used Yuming's songs in his popular animations; Takeuchi Mariya's 'Plastic Love' (1984) became a global hit in 2018 owing to YouTube recommendations; and Chiaki Naomi's 'Rouge' (1977) written by Nakajima Miyuki has been covered in several languages, including Chinese, Thai and Finnish. Furthermore, Itsuwa Mayumi and Yano Akiko recorded their debut albums in the United States and have collaborated with such influential musicians as Carole King and Lyle David Mays. Therefore, although I discuss the female singer-songwriters in a Japanese context, several aspects about them should be of wider international interest.

My argumentation is informed especially by academic accounts of female musicians and creativity, including those by Citron (1993), McClary (2002), Warwick (2007) and Whiteley (2000). All of their views are naturally not applicable to Japan as such, but as Mehl (2012) has demonstrated, many of the gender discriminatory practices in Western music have been rooted in Japan since the late nineteenth century. To contextualise Japan-specific practices and gender expectations, I will refer to the feminist studies on Japan by Inoue (1981; 2009), Shigematsu (2005; 2012) and Ueno (2009). By adapting Small's (1998) concept of 'musicking', I also conceptualise the positive valuation of female singer-songwriters as a musical act reflecting and constructing social values. I shall begin by situating female singersongwriters in Japanese music production and society of the 1970s. This serves as background against which I next examine female singer-songwriters from the viewpoint of issues typically pertaining to creative female musicians. After this, I conclude by suggesting the importance of examining these matters from the viewpoint of gender equality. 


\section{Locating female singer-songwriters in Japanese popular music of the 1970s}

There is not enough space to explain all the peculiarities of Japanese production models of the 1970s here. As already suggested in the introduction, however, changes in the 1960s and 1970s bear many similarities to those in Europe and America especially related to concepts such as commercialism, authorship and authenticity. My emphasis here is on recognising the discourses related to these matters rather than agreeing or disagreeing with them (cf. Moore 2002; Negus 2011, p. 613). Even despite individual differences between female singer-songwriters, discerning their position in different production models serves as crucial background for understanding why they can be discussed together in the first place. This pertains especially to why they were able to debut in a production system that was dominated by men (Igarashi 1999).

A definition of a singer-songwriter involves several issues (Till 2016, pp. 291-5) but my viewpoint in this article intentionally remains at a general level: 'singersongwriter' stands for a solo artist who (1) composes most of her music, (2) writes most of her lyrics and (3) performs (sings, in many cases self-accompanied on the piano or the guitar) these songs herself. This definition does not address other attributes often associated with singer-songwriters, such as notions of subjectivity, because such conceptualisations were not that prevalent in Japan. Above all, the female singer-songwriter is an author: someone who expresses herself through music but not necessarily in a manner that claims to reflect real experience. Drawing a line is, of course, often complicated. For example, although Ōta Hiromi (b. 1955) wrote some of her songs and often accompanied herself on the piano, she was not presented as a singer-songwriter in the media or marketed as such. In comparison, Iruka (b. 1950) did not write all of her music despite being recognised as a singer-songwriter; in fact, her most well-known song, 'Nagoriyuki' (Lingering Snow, 1975), is a cover. Therefore items 1 and 2 include the qualified 'most'. For example, quite notably Iruka wrote most of her material in the 1970s, whereas Ōta did not. ${ }^{3}$

Generally, popular music production of the 1970s was characterised by a division to two different approaches: styles emphasising musicianship and authorship of one's own material, and those based on an 'industrial' process in which the musician had less authority in the production. The former comprised various genres by different names, whereas the latter is here called collectively kayōkyoku. Both are introduced in more detail in Table 1, which compares production models from the late 1950s when the first alternatives to older record companies emerged to the late 1980s when J-pop assimilated older genre names and production models.

Table 1 presents the genres highlighting musicians' authorship as a continuum rather than as separate music styles. There are musical differences between these genres (Kuji 1982, p. 35), but here I suggest continuity in the culture of production and discourses of musicianship. This conceptualisation is informed by the fact that many of those who debuted as folk singer-songwriters (such as Yoshida Takurō and Inoue Yōsui) were later recognised as New Music, whereas those who debuted

3 Of her 131 album-released songs in the 1970s, Ōta wrote either the music or the lyrics - typically both for $19(14.5 \%)$, whereas Iruka wrote the music or the lyrics (typically both) for 55 (c. $83 \%$ ) of her 66 songs. By comparison, similar numbers for Yuming and Nakajima Miyuki are, respectively, 81 $(100 \%)$ and $62(100 \%)$. Including the few songs released only as singles would not notably alter these numbers. 
Table 1. Adapted from Lehtonen (2019, p. 279).

Divisions in Japanese post-war popular music (c. 1958-1989)

\begin{tabular}{|c|c|c|}
\hline & Kayōkyoku & Styles emphasising musicianship \\
\hline Principal genres & $\begin{array}{l}\text { Kayōkyoku (general name for } \\
\text { popular music), enka, idols, wasei } \\
\text { pops }\end{array}$ & $\begin{array}{l}\text { Rock, folk, New Music, City Pop, } \\
\text { Shibuya-kei. With certain } \\
\text { reservations, rockabilly and Group } \\
\text { Sounds }\end{array}$ \\
\hline $\begin{array}{l}\text { Production } \\
\text { model }\end{array}$ & $\begin{array}{l}\text { Emphasis on pursuit of commercial } \\
\text { success; composer, lyricist, } \\
\text { performer, arranger and producer } \\
\text { typically separate individuals. } \\
\text { Singers typically employees of a } \\
\text { management company that } \\
\text { oversaw their public images }\end{array}$ & $\begin{array}{l}\text { Insisting on musical authenticity and } \\
\text { musician-centredness. Artists } \\
\text { typically performed their own } \\
\text { material and oversaw their own } \\
\text { public images }\end{array}$ \\
\hline $\begin{array}{l}\text { Record } \\
\text { companies }\end{array}$ & $\begin{array}{l}\text { Established company emphasising } \\
\text { the role of the producer }\end{array}$ & $\begin{array}{l}\text { Company either founded by } \\
\text { musicians or otherwise } \\
\text { highlighted musicianship }\end{array}$ \\
\hline $\begin{array}{l}\text { Age of listeners } \\
\text { and musicians }\end{array}$ & Of all ages & $\begin{array}{l}\text { Mostly in their late teens or twenties } \\
\text { (at time of debut) }\end{array}$ \\
\hline $\begin{array}{l}\text { Main stage of } \\
\text { performance }\end{array}$ & $\begin{array}{l}\text { Television shows and large-scale } \\
\text { concerts }\end{array}$ & $\begin{array}{l}\text { Depending on genre, intimate stages } \\
\text { or large-scale concerts. Fewer } \\
\text { appearances on television }\end{array}$ \\
\hline $\begin{array}{l}\text { Musical } \\
\text { influences }\end{array}$ & $\begin{array}{l}\text { Contemporary popular music in } \\
\text { America, Europe, and Japan. } \\
\text { Assimilating trends introduced } \\
\text { by musician-centred styles }\end{array}$ & $\begin{array}{l}\text { Contemporary popular music in } \\
\text { America and Europe }\end{array}$ \\
\hline $\begin{array}{l}\text { Social and } \\
\text { artistic view }\end{array}$ & $\begin{array}{l}\text { Conformist, sometimes } \\
\text { conservative; not difficult or } \\
\text { menacing; neutral on social } \\
\text { issues. Compare with American } \\
\text { middle-of-the-road pop }\end{array}$ & $\begin{array}{l}\text { Embracing novelty; musically and in } \\
\text { folk and rock, sometimes explicitly } \\
\text { subversive. Compare with } \\
\text { European and American rock, folk, } \\
\text { and singer-songwriters associated } \\
\text { with authenticity }\end{array}$ \\
\hline $\begin{array}{l}\text { Relationship of } \\
\text { lyrics and } \\
\text { melody }\end{array}$ & $\begin{array}{l}\text { Emphasis on adapting melodies to } \\
\text { intonation and rhythm of spoken } \\
\text { Japanese language of the lyrics }\end{array}$ & $\begin{array}{l}\text { Emphasis on musical content and } \\
\text { sound, sometimes at the expense } \\
\text { of lyrics }\end{array}$ \\
\hline
\end{tabular}

in New Music were later labelled under City Pop. A factor enabling differences in production models is related to the record companies from which these musicians debuted. The originally underground nature of folk and rock of the 1960s spurred the foundation of musician-based companies, such as URC, Elec and later For Life Records, which offered an alternative to the established record industry (Azami 2004, pp. 168-80). This resulted in musicians producing each other's albums and performing on them as studio musicians in a manner that prioritised the artist's wishes. The discourse of musicianship also pertained to authorship of one's material and precisely this aspect was considered as authenticity by musicians and fans alike (Bourdaghs 2012, pp. 163-94).

In contrast with these genres is kayōkyoku. Today, the term kayōkyoku (or Shōwa kayō, 'popular songs of the Shōwa period' [1926-1989]) is used loosely to refer to post-war popular music before the appearance of J-pop at the end of the 1980s but in the 1970s it possessed a more specific meaning as a musical genre defined by its 
production model. Typically, kayōkyoku assimilated and commodified musical and sometimes habitual characteristics of styles emphasising musicianship while keeping to its production model that divided the roles of performers, songwriters, management and producers, giving the most authority to producers and management companies. Television shows formed an indispensable medium in the dissemination and standardisation of kayōkyoku (Ogawa 1988, pp. 110-6). Although musically hybrid and flexible, kayōkyoku constituted a genre by its distinctive qualities in both production and textual content (cf. Holt 2007). In practice, however, its boundaries with the genres emphasising musicianship were far from clear in terms of musical style and collaborators. This is because many of the artists emphasising their musicianship ended up working for the kayōkyoku industry as songwriters.

Of the genres emphasising musicianship, New Music (nyū myüjikku) is of particular interest here; so strong was the presence of female singer-songwriters in establishing the genre that discussion on it should also be understood as their origins. ${ }^{4}$ Like kayōkyoku, New Music was a hybrid genre comprising different musical styles to the degree that it was often said to have brought down stylistic barriers (e.g. Aono 1976, p. 125). Above all, it was distinguished by certain assertions related to production and the position of musicians as individual authors. While these assertions were grounded in earlier rock and folk, New Music differed from them in relation to its notion of commercialism. As in Europe and America, Japanese rock and folk musicians who 'went commercial' were originally criticised for betraying their audience. A fitting example is Yoshida Takurō, a singer-songwriter who became a teen idol marketed as 'the prince of folk' ( föku no purinsu), which resulted in fierce reactions from the original folk audience (Take 1999, p. 140). By the time that New Music emerged in the early 1970s, however, such criticism was no longer prevalent (Ogawa 1988, p. 46). An analogy with other countries perhaps helps to demonstrate its position. Whereas earlier singer-songwriters were like American folk singers or Italian 'unprofessional' female cantautori whose "quality" and "honesty" ... was untainted by commercial matters' (Conti 2016, p. 40), those debuting in the 1970s were more like the 'professional' singer-songwriters openly sensitive to commercial success (Borshuk 2016).

This emancipation of commercialism was inseparably intertwined with social developments. Affluence brought upon by seemingly unstoppable economic growth led to the image that Japan had become a uniform middle-class society, which calmed subversive movements and propelled the conception that all Japanese were equal in economic and cultural terms (Tsurumi 1984, pp. 108-38; Ivy 1993, p. 241). This spurred a consumerist boom that was centred around commercial images of an urban, middle-class lifestyle - a phenomenon fostered by rapid urbanisation that also entailed significant changes in the lives and identities of contemporary Japanese (Okamoto 2015; Aoyagi 2005, pp. 82-3). ${ }^{5}$ New Music became a musical embodiment of these changes by emitting an aura of the cosmopolitan lifestyle one continuously encountered in commercial imagery aimed at the new middle-class

4 The establishment of New Music is often associated with Yuming in both academic and popular histories (Ogawa 1988, p. 51; Take 1999, p. 169). Yuming, however, stated her dislike of the term (Matsutōya 1984, p. 9).

5 The post-war decades were characterised by rapid urbanisation. For example, 38 per cent of Japan's population lived in cities in 1950 whereas in 1970 the number had risen to 72 per cent (Okamoto 2015, p. 79). 
audience. For example, Yuming (Matsutōya 1984, pp. 9-10) famously defined her music as 'middle-class sound' (chūsan kaikyū saundo), which was typically characterised as 'stylish' (oshare) and 'urban' (tokaiteki) (Yoshida 1977; Sakai 2013). As a soundtrack for the urbanised lifestyle which presented consumption as a virtue, New Music did not assert its authenticity as anti-commercialism but instead distinguished itself from kayōkyoku by its celebration of individual creatorship. This carefully constructed image was aptly crystallised in a comment by a management company representative: 'When kayōkyoku tops the charts it's thanks to the production organisation but in New Music it's all about the musician, including everything from the artist's sound and lyrics to philosophical aspects' (Anonymous/Takeuchi 1981, p. 145). ${ }^{6}$

Since the late 1960s, male singer-songwriters had constructed this distinction by avoiding appearances in contexts associated with kayōkyoku singers, especially in music shows on television. Female singer-songwriters inherited this strategy in their negotiation of their public images. For example, Yagami Junko described her position in the following terms: 'So, I don't want to appear on television shows. If I was to appear with the kinds of celebrities that get applauded by screaming fans, my image will also be received that way. That would be inexcusable to long-time fans, wouldn't it?' (in Anonymous/Yagami 1978, p. 172). Whereas Yagami speaks of 'celebrities' (tarento), Yuming negotiated her position even more clearly by referring to 'singers' (kashu): 'You see, I'm not a singer. If I was a singer, there would be no meaning if I was not applauded by screaming fans, right?' (Matsutōya 1984, pp. 31-2). In other words, both Yuming and Yagami portrayed themselves as authors rather than 'mere performers' who were more likely to be applauded as celebrities, not as musicians. As Stevens (2008, pp. 49-50) has crystallised, the perceived difference between singer-songwriters and more visually presented kayōkyoku singers was that singer-songwriters spent more time in the studio and in concert halls than on television programmes. This even led to a momentary crisis of the 'top $10^{\prime}$ music shows, as they could not claim to present the most popular Japanese singers anymore (Ogawa 1988, p. 114).

However, this romanticised notion of disinterest in the mass media is deceiving. While singer-songwriters certainly avoided appearing on kayōkyoku shows, their songs were constantly utilised in television dramas and commercials, both of which had an immense impact on record sales (Ogawa 1988, p. 71). Using again Yuming and Yagami as examples, Yuming's 'Ano hi ni kaeritai' (I Want to Return to that Day, 1975) became the best-selling single of 1975 as the theme song of the television drama Katei no himitsu (Family Secrets); similarly, Yagami's 'Omoide wa utsukushisugite' (Memories Are Too Beautiful, 1978) became a sales hit after having been used as the opening song for the music programme Cocky Pop, which sought to bridge the gap between kayōkyoku and New Music. Female singer-songwriters also wrote songs for kayōkyoku singers; in fact, the subsequent rise of 'idols' (aidoru) young kayōkyoku singers 'manufactured' by their management companies to the minutest detail (Inamasu 1989; Aoyagi 2005) - has even been attributed to the songwriting skills of female singer-songwriters such as Yuming, Takeuchi and Ozaki Amii (b. 1957) (Ogawa 1988, p. 155; Nagai 2013, p. 141). Furthermore, their interviews were typically published in such celebrity and fashion magazines as Myōjo,

\footnotetext{
${ }^{6}$ All translations from Japanese in this article are by the author.
} 
Heibon and Seventeen, which equally discussed kayōkyoku singers and other media personalities. Nevertheless, female singer-songwriters' status on television was different from kayōkyoku singers and their interviews typically put a notable emphasis on music. From this position, they securely maintained their identities and images as creative musicians while also topping the sales charts as mainstream pop.

Of course, not everyone was identical in this respect. For example, although certainly keeping her distance to kayōkyoku production as a musician, Nakajima Miyuki emphasised feeling affinity with kayōkyoku itself: 'I like kayōkyoku; I also often watch the television shows. I'm called a "singer-songwriter" but I don't own any folk or rock records. And I've never listened to Yuming' (Anonymous/Nakajima 1976, p. 174). Whereas Nakajima also stated that she did not regard her songs written for kayōkyoku singers as that different from her own songs (Anonymous/Nakajima 1978, p. 120), Yuming even used the penname Kureta Karuho when writing kayōkyoku to distance herself from its productional context. ${ }^{7}$ It may well be that Nakajima deliberately constructed her image as somewhat different from that of others (especially Yuming, who was often labelled her 'rival') but more importantly, her comments demonstrate that the recognition of kayōkyoku did not necessarily negatively affect one's position as an author.

This tendency became even more prevalent towards the end of the 1970s, when kayōkyoku production increasingly commodified the female singer-songwriter as a marketable concept. Those singer-songwriters who debuted as kayōkyoku artists did retain their authorship as songwriters but their management companies began to have increasingly more authority on their work. For example, it was not atypical that earlier singer-songwriters clung to their own vision as musicians even when arrangers tried to make their music more commercially attractive (Hagita 2018, p. 46), whereas in kayōkyoku the producer held the most power. This applied also to the constructions of public figures; singer-songwriter Kubota Saki (b. 1958), for example, was to be presented as a big star from the beginning (Hagita 2018, p. 53). Kayōkyoku singer-songwriters also began to appear on television shows, which meant increasing emphasis on the visual aspects of performance.

This was a natural development considering how kayōkyoku had successfully assimilated and commodified subversive trends before (Minamida 2014, p. 136). However, adhering to kayōkyoku practices had its downsides for many women. For example, although Takeuchi Mariya wished to perform as a singer-songwriter, the media was more concerned with her visual appearance and often presented her in a manner similar to kayōkyoku idols. Eventually, Takeuchi felt such a huge gap between her aspirations and media representations that she refrained from public performances and focused on writing songs for other singers for some time (Anonymous/Takeuchi 1981, p. 145; Take 1999, p. 180). Similar issues escalated in the 1980s. Okamura Takako (b. 1962) and Nakamura Ayumi (b. 1966), among others, had to find a balance between their own desires as musicians and those of their management, typically emphasising visual aspects (Take 1999, p. 250; Lehtonen 2019, pp. 460-3). Singer-songwriters becoming increasingly involved in kayōkyoku production raised doubts about their artistic integrity (Anonymous 1978) and eventually

${ }^{7}$ Kureta Karuho is a wordplay on Greta Garbo. Yuming's decision to use a penname was uncommon; for example, Nakajima, Yagami, Takeuchi Mariya, Ozaki Amii, Yoshida Minako (b. 1953) and Ishikawa Yūko (b. 1958) never used pennames when writing songs for kayōkyoku singers. 
marked the end of the authenticity associated with New Music in the early 1980s (Ogawa 1988, p. 155).

\section{New Music, feminism and social subversion}

As the discussion above demonstrates, female singer-songwriters did typically not write music addressing political issues nor were they considered as feminists. In the rare cases that subversion has been suggested in New Music, it has been located in a musical rather than societal context. In this, the image of female singersongwriters resonates with Lankford's (2010, p. 8) discussion of their foreign counterparts as introspective rather than political, thus perceived as safely conformist and non-subversive. However, concentrating solely on fixed definitions of subversion such as anti-commercialism or explicit commentary of societal issues leaves much unseen. As Kutulas (2010) and Shumway (2014, pp. 148-74) demonstrate, there are several attributes that render American female singer-songwriters of the 1970s feministic, albeit not necessarily overtly so. This resonates strongly with their Japanese counterparts. After all, 'music and its procedures operate as part of the political arena - not simply one of its more trivial reflections' (McClary 2002, p. 27). In other words, music always asserts something. This is typically recognised only when music explicitly breaks a taboo but there are also more subtle forms of subversion.

For example, a certain mode of subversion was inscribed to New Music itself. By originally declining appearances on kayōkyoku shows, singer-songwriters were, by extension, rebellious against the Japanese post-war paradigm of national homogeneity that was considered to penetrate all layers of Japanese society (Befu 2001). In his discussion on the media representations of this paradigm, Tsurumi (1984, pp. 121-3) notes that established television programmes at that time - especially the New Year's national music show Kōhaku utagassen (Red-White Song Contest) substituted nationalistic symbols of the war era and contributed to the construction of new discourses of nationality by functioning as a musical representation of the homogeneity discourse. In other words, by boycotting music programmes on television, New Music also indirectly rebelled against the paradigm of national homogeneity. ${ }^{8}$ This is especially apparent in the way New Music was originally seen as the opposite of enka - the genre that most explicitly asserted national homogeneity by its articulations of 'Japaneseness' (Yano 2002; Wajima 2010).

Similarly, the concept of the female singer-songwriter itself and its assertions of authorship, creativity, and professionalism embodied political implications from a gender point of view (cf. Reitsamer 2018; Citron 1993). These implications appear especially fascinating when examined in a broader socio-cultural context. The early 1970s saw the rise of a radical women's liberation movement (üman ribu) and, in its wake, the emergence of more moderate discourses on improving women's social agency. 9 The subversive and action-oriented women's liberation movement was disillusioned by the male-centred and fundamentally patriarchal assertions of the social movements of the 1960s and formulated radical feminist theories to introduce

${ }^{8}$ Discussion here is limited to the early and mid-1970s. Eventually even Yuming appeared in Kōhaku utagassen in 2005.

9 For a comprehensive English-language account of the history and discourses of Japanese feminisms, see Mackie (2003). 
a gendered viewpoint to global social inequality. It was also highly antiestablishment and sought to liberate women by fundamentally restructuring society rather than endorsing female participation in already existing social structures (Shigematsu 2012).

Although the more radical approaches of the women's liberation movement were even ridiculed in the media (Shigematsu 2012, p. 79), it nevertheless paved the way for the rise of more moderate organisations pursuing women's emancipation in the framework of existing social structures in such fields as workplace, media and education. The issues raised by these organisations had become prominent in the wake of economic growth and rapid urbanisation, both of which marked changes for the social position of women. Owing to urbanisation, the nuclear family gradually replaced the older tradition of three generations under one roof, which resulted in a considerable rise in the number of women in the workforce, yet their position remained weak compared with that of their male counterparts (Ochiai 1996). This was due to the dominant paradigm that associated women's social duties with the private space (home) and men's duties with the public space (workplace) (Ueno 2009; Edwards 2014). Since family was commonly regarded as the most important social unit, the expectation that women would be responsible for the domestic sphere was associated with national order under the ideal of 'good wife, wise mother' (ryōsai kenbo; Uno 1993). Consequently, women were strongly expected to leave their careers upon marriage or, at the latest, upon pregnancy, to be able to fulfil their social duties (e.g. Shiota 2000; Ochiai 1996). This expectation resulted in discriminatory practices in work and education and was also apparent in the typical media representation of women primarily as mothers and (house)wives (Inoue 2009; 1981).

To tackle these issues, many feminist groups aimed to subvert the dominant paradigm by endorsing women's emancipation in the framework of existing structures. They were eventually successful in drawing attention to their goals: especially after the United Nations launched its Decade of Women in 1975, improving women's societal position became a largely recognised and debated issue in Japan (Mackie 2003, pp. 174-201). Consequently, feminism gained ascendancy in public discussion (Ehara 1993). For example, 'soaring women' (tonderu onna) was a slogan referring to women with a high level of social agency and freedom in a positive manner and became a buzzword of the 1970s. The positive image of female emancipation eventually fostered concrete social changes, such as the enaction of antidiscrimination laws. ${ }^{10}$

After feminism had become a mainstream discourse, images of female emancipation were also adopted for commercial purposes. This development was, again, intertwined with urbanisation and economic growth. As both required women to adjust to new ideals of middle-class lifestyle in cities (Ueno 2009), the consumerist boom and its cultural products became instrumental in providing women with tools to manage this transition (Inoue 2009; Aoyagi 2005, pp. 82-3). With the rise

10 This article focuses on the progress in the 1970s but it should be noted that despite this hype on women's emancipation, the results were ultimately a disappointment for many in the 1980s. For example, the Equal Employment Opportunity Law, which was implemented in 1986 to provide equal employment opportunities for women and men, simply resulted in new practices for discrimination (Ueno 2009, p. 121). Furthermore, certain discourses in mainstream feminism of the 1980s have been criticised for aiming to improve women's social position only in the framework of conventional gender roles instead of promoting fundamental social change (Shiota 2000). 
of feminism, the commercial mass media began to present images of an urban and cosmopolitan lifestyle that associated women's social independence with the freedom of individual consumption (Shigematsu 2005, p. 564). Putting aside the fact that this trend quite notably compromised the anti-capitalist and anti-establishment assertions of the early women's liberation movement, the new image of women as individuals was nevertheless significant for women's emancipation at large in that it dissolved earlier media representations that had focused on women solely as mothers and housewives (Inoue 2009, p. 5).

This development directly relates to the discussion on New Music and female singer-songwriters. As they represented a commercial mode of production and did not explicitly address feminist issues in their songs, they certainly cannot be considered a musical embodiment of the radical women's liberation movement. However, female singer-songwriters do closely relate to the more moderate feminist discourses and their commercial representation as a concrete manifestation of 'soaring women'. Since music forms an important arena for constructing, reflecting and negotiating gender roles (McClary 2002), female singer-songwriters' activities provided a concrete exemplar of women's social agency for the wider social sphere. This is also reflected in Yuming's later statement that she possibly represented 'backstage women's liberation' (misshitsu no üman ribu) - a rare example of associating female singer-songwriters with women's movements (in Chikushi 1984, p. 54). By thus closely linking with the social developments at large, female singer-songwriters' emergence suggests much more than only the musical change with which they are more commonly associated.

\section{Female singer-songwriters as 'backstage women's liberation'}

I shall next elaborate on the social significance of female singer-songwriters through the following five points:

(1) female agency in music production;

(2) successful negotiation of social expectations;

(3) positive valuation of female genius;

(4) social context of emergence; and

(5) position in historiography.

The nexus of these points best discloses why the emergence of female singersongwriters should be considered a significant phenomenon in both musical and social spheres.

\section{Female agency in music production}

Prior to the 1970s, women's roles in popular music production were very limited. Exceedingly rare exceptions of successful female lyricists were Iwatani Tokiko (1916-2003) and Arima Mieko (1935-2019). Some songs composed by women do exist mostly just before the 1970s but these are notably few. Limited possibilities for female participation were related not only to song-writing but were also obvious in production and management (Igarashi 1999, pp. 84-5). One of the very few exceptions was producer Watanabe Misa (b. 1928), who co-founded the influential management company Watanabe Productions in 1959. However, Watanabe's position did not provide a general exemplar for promotion of female participation; it was 
only in the 1980s that women began to have a firmer foothold in production positions (Igarashi 1999).

In this context, it is remarkable that the emergence of female singer-songwriters also marked the large-scale introduction of female songwriters to Japanese popular music. By suggesting that this was significant, I do not want to reify the romantic notion of the ultimate authorship of a song belonging to its composer and lyricist (cf. Bentley 2018). Popular songs arise from a collaborative process (Frith 1996, p. 240) and distinguishing their 'author' entails several complexities (Negus 2011, pp. 608-9). For example, singers can possess an elevated level of perceived authorship even in cases where they have not participated in writing their songs (Negus 2011, p. 619). In Japan, such examples of successful women would be Misora Hibari (1937-1989) and Fuji Keiko (1951-2013), both highly acclaimed enka singers with images strongly informed by their personal backgrounds. It does not matter that these images were at least partly constructed by their (male) producers, as was later revealed; their position was different from that of songwriters but can certainly be acknowledged as authorship (Tong 2015).

However, I maintain that two aspects did significantly change with the emergence of female songwriters. The first one is textual: that women's own voices became widely heard in popular music. The second one is productional: that women became actively involved in music production. These two are intertwined in several ways and extend to the larger social sphere as a concrete promotion of female agency. It is in this context that the idea of the perceived author as composerlyricist becomes relevant. Although Hoke (1991, pp. 258-9) justly draws attention to the fact that women have always excelled as singers, McClary (2002, p. 151) notes that while opera, for example, allows women to be presented as stars on the stage, the gendered discourses reinforced and constructed in libretti and music by men have resulted in offering up the female as spectacle while guaranteeing that she will not step out of line'. Whether in opera or on a pop record, female performers are often presented as musicians who sing in the voice of a male-dominated production rather than their own (Warwick 2007, pp. 94-5).

For example, the history of kayōkyoku is full of examples of women singing about female emotions and desires that strongly suggest ideal ways of being a woman. However, these idealisations were virtually always written by male lyricists and typically represented a biased view of femininity. Although there were naturally exceptions to this rule, the quintessential portrayal focused on female characters devoting themselves completely to the men they love, thinking only about them, and crying over them (Zettsu 2002 and 2005; Take 1999, p. 168-9). By thus articulating the common view that women and men were incomplete without each other and, by extension, a family (Edwards 2014), these portrayals effectively perpetuated the paradigm that confined women to the private space (Inoue 1981, pp. 110-21). It is easy to recognise that in its diminishing of female participation and agency, popular music reflected and reified general tendencies of Japanese society.

Thus, the involvement of female songwriters in music production represented concrete female agency previously unheard of in Japanese popular music. Although I here emphasise this as concrete social participation, several reasons speak for a more detailed textual analysis. Lyrics especially enable subtle articulations of both women's identity and agency in contexts previously dominated by men (Greig 1997, p. 169; Warwick 2007, p. 112; Kutulas 2010). Previous studies suggest that the side of female identification was especially important for listeners in the works 
of Yuming and Nakajima, who presented different aspects of womanhood: Yuming was described as 'light and sophisticated', while Nakajima was depicted as 'dark and moody' (Stevens 2008, p. 47; Kikuchi 2008, p. 248).

Although much more detailed analysis than can be presented here would be necessary to distinguish differences among different portrayals of women by female and male lyricists, previous writers have suggested such differences. Essayist Sakai Junko, for example, has elaborated on how remarkable it was for female listeners that Yuming diversified the portrayal of women in popular music by writing about women's experiences from a woman's point of view. In such songs as 'Umi wo miteita gogo' (The Afternoon I Watched the Sea, 1974), Yuming presented an image of a woman who refused to cry over her boyfriend even when facing a break-up with him. Sakai (2013 pp. 26-9) interprets this as a statement articulating that women's happiness did not rely only on men or marriage and that it should be acceptable for women to think so. Another fitting example is ' 14 banme no tsuki' (Moon on the Fourteenth, 1976), in which the heroine anticipates what will happen after she has confessed her feelings to the person she secretly loves. Sakai (2013, pp. 43-55) views this as a subtle negotiation of female agency, as it depicts a woman acting on her own will in a situation that was commonly thought of as calling for a man's initiative, showing boldness that is further emphasised by the energetic music. Hence, by contradicting the stereotypical portrayals of women, these songs also represented an alternative to common narratives about gender roles.

Furthermore, countless lyrics by female singer-songwriters include no reference to romance at all. For example, Itsuwa Mayumi's 'Shōjo' (Girl, 1972), Taniyama Hiroko's (b. 1956) 'Gingakei wa yappari mawatteru' (The Milky Way Keeps on Rotating, 1972) and Nakajima Miyuki's 'Jidai' (Era, 1975) depict women contemplating life and the flow of time, which again represents a very different portrayal of women from typical kayōkyoku lyrics (Shimazaki 2006; cf. Ochiai 1996, p. 116). This is not to say that lyrics by female singer-songwriters would not occasionally have portrayed women in a manner similar to kayōkyoku representations but as Sakai (2013, pp. 53-4) notes, even in these cases it was significant that the lyrics were written by women themselves as this rendered the adherence to social expectations a matter of women's own choice. Above all, by presenting women as desiring subjects rather than desired objects, female singer-songwriters provided their listeners with exemplars of womanhood previously unavailable in Japanese popular music and represented what Japanese feminist scholars dub as 'women's culture': culture made for women, typically by women (Inoue 2009, pp. 2-3; Shigematsu 2005, pp. 556-7).

Of course, understanding female listeners' process of identification with female singer-songwriters would require more careful observance of fan experiences. Other equally important aspects to address would be differences in the use of voice and body between singer-songwriters and kayōkyoku singers. Naturally, the same also pertains to the act of composing; much more detailed analysis would be required to point out differences in musical portrayals of women by female and male composers or arrangers. Based on previous analyses, however, it seems that female singer-songwriters did exhibit musical versatility that was possibly gendered due to certain social expectations. Kikuchi (2008, p. 248) notes that female singersongwriters were typically not as insistent about clinging to a certain musical style as were male musicians before New Music. For example, Itsuwa Mayumi and Takeuchi Mariya declared genre definitions altogether needless (Anonymous/ Itsuwa 1972, p. 189; Anonymous/Takeuchi 1978, p. 53). In this, women's 
music-making demonstrated flexibility that was possibly not available for male musicians. This tendency was also apparent outside Japan (Warwick 2007, p. 134; Kutulas 2010 , p. 696). It may well be that this hybridity was originally an expression of female identity; nevertheless, New Music eventually established a framework of flexibility also for male musicians, which is a concrete example of female singer-songwriters having an impact on Japanese popular music at large.

This impact became even more apparent when many women were requested to participate in writing songs for the kayōkyoku industry. In fact, the popularity of many idol singers produced by the kayōkyoku industry has been attributed to the song-writing skills of women in both academic and popular contexts precisely because of a perceived feminine aspect that they were able to introduce to kayōkyoku (Ogawa 1988, p. 155; Nagai 2013, p. 141). As the kayōkyoku industry had typically been conservative in its representation of women and its diminishing of female agency in music production, this change was especially important from a social viewpoint as it recognised women's creative skills. After singer-songwriters had demonstrated that music written by women could be commercially successful, the kayōkyoku industry soon began to commission songs from female composers and lyricists who were not originally performing musicians themselves. Eventually, their agency also extended to other aspects of production. For example, Yoshida Minako began producing the albums by younger female singer-songwriters and the first notably popular all-female groups, such as Princess Princess, Shonen Knife and Sugar, debuted in the early 1980s. Thus, by providing an exemplar of female agency, the appearance of female singer-songwriters initiated a momentous change in Japanese popular music (cf. Stanlaw 2000).

\section{Successful negotiation of gendered social expectations and public recognition}

'Public recognition' here refers to the volume of sales and media coverage; recognition as explicit positive valuation will be addressed below. Frith (1996, pp. 15-6) notes that the excessive emphasis on sales figures to define popularity easily leads to biased views of musical or social significance based solely on consumption. Nevertheless, sales figures can be important in that they embed societal implications. This is best explained with Small's (1998) concept of musicking and the idea that music is an act that reflects, constructs and reaffirms social and cultural values. If we next adopt Sewell's (1999) conceptualisation of culture as a dialectic between system and practice, sales figures and wide media coverage (practice) demonstrate recognition of women as professional, creative individuals, which is reflective of social values (system).

This is especially notable in that the singer-songwriters' audience was not biased in terms of gender; based on contemporary media coverage, their fans included women and men alike. Rather than by gender, the audience was divided by age but precisely the fact that young listeners supported female singersongwriters reflected a shift in social values (Take 1999, p. 170; Yoshida 1977). This is because public recognition, defined in these terms, entails the acknowledgement of female professionalism. The concept of 'professionalism' typically embeds several issues for female musicians because of social expectations that discourage women's creativity (Citron 1993, pp. 84-7; Whiteley 2000; Warwick 2007). However, with women singer-songwriters, the stigmas of female professionalism became almost a non-issue. This was demonstrated not only in their successful 
careers but also in boastful statements such as Yuming proclaiming herself a genius (Matsutōya 1984, p. 7) or Yano Akiko stating that she hates those who do not buy her records or come to her concerts (Anonymous/Yano 1977, p. 51). Both are notably strong statements in a culture that regards modesty as a virtue, especially for women, and demonstrate success in negotiating gendered social expectations.

It should be noted here that female singer-songwriters were still subject to certain expectations and constraints specific to women. For example, their outward appearances were frequently commented upon in the media - even in articles that otherwise celebrated their creativity. One article about Yagami Junko praised her musical skill but also compared her looks with those of a 'yam' (Anonymous/Yagami 1978, p. 172). Bourdaghs (2012, p. 185) describes how he was repeatedly told that Yuming is popular 'despite not being beautiful'. Another expectation specific to women is related to marriage and motherhood. This is a universal expectation (Bayton 1997, p. 48), but as discussed above, it was a particularly strong one in contemporary Japan and was clearly recognised by female singer-songwriters. For example, Yuming initially declared her musical career over and focused on being a housewife after getting married in 1976 (Matsutōya 1984, pp. 121-2) and Yagami stated that she would get married at 25 and then make music only as a hobby as she 'would not be able to manage both' (in Anonymous/Yagami 1979, p. 88). As in the history of creative female musicians in general (Citron 1993, p. 84-5), social expectations clearly also posed a contradiction to female professionalism in Japan of the 1970s.

Nevertheless, female singer-songwriters ultimately managed to negotiate a position different from most female kayōkyoku singers, who more typically adhered to social expectations related to motherhood and career. ${ }^{11}$ First, this is apparent in the construction of their authenticity by declining to be presented as visual objects in kayōkyoku programmes. Of course, live performances did present them on the stage visually but also in this context, singer-songwriters were able to articulate their contempt if valuated as something else than musicians. For example, Yagami Junko emphasised how she wished the audience to concentrate on listening to her music rather than screaming her name in awe (in Anonymous/Yagami 1979, p. 88). Furthermore, the visual presentation of kayōkyoku singers entailed regulated bodily movements dictated by male producers (Ogawa 1988, p. 130-3). Declining from such fixed modes of visual presentation, authorship in New Music also entailed the female singer-songwriter's agency over her body - and by extension, the bodies of the women who listened to her (cf. Warwick 2007, pp. 56-64). Second, singer-songwriters were eventually able to defy the expectation of women to leave their careers upon marriage and childbearing. For example, Yuming became tired of being a housewife and soon returned to recording and performing to even much more success than before; in contrast, Takeuchi Mariya focused on writing songs for kayōkyoku singers while staying at home taking care of her child (Kamidate 2019, pp. 112-3). There are countless examples of female singer-songwriters who have successfully continued their careers despite social expectations. Many of them are active and highly popular musicians today, having celebrated their fortieth anniversary as singer-songwriters in the 2010s. ${ }^{12}$

11 A concrete demonstration of this was the social controversy caused by the Hong Kong-born kayōkyoku singer Agnes Chan (b. 1955) upon her decision to return to work soon after giving birth in 1987 (see Ehara 1993, pp. 57-8).

12 In addition to Yuming and Takeuchi, these include, among others, Nakajima Miyuki, Yano Akiko, Yagami Junko and Okamura Takako. 
Important here is not only the fact that this kind of negotiation took place, but also that the continuing popularity of these female musicians even after marriage and childbearing demonstrates acceptance of their roles as both professional female individuals and mothers/wives. In other words, public recognition shows that their negotiation succeeded. This made female singer-songwriters a concrete manifestation of the change that movements seeking female emancipation in Japan strived for.

\section{Positive valuation of female genius}

Naturally, one can still argue that the type of public recognition witnessed in popularity does not necessarily equal the celebration of women's creative skill. As popular music is typically known through performers rather than songwriters, it is hypothetically possible to ignore the 'songwriter' and focus solely on the 'singer', in which case singer-songwriters would not appear as that different from kayokyoku singers. However, the focus solely on performance is easily countered with the fact that the song-writing skills of female singer-songwriters were specifically celebrated for their novelty: their creativity was not only acknowledged but also evaluated positively. Although this concerned many female singer-songwriters, it is best exemplified by discussing Yuming. ${ }^{13}$ This is because she is commonly considered a pioneer who established the category of female singer-songwriter in Japan. Various influential figures, ranging from folk singer-songwriter Yoshida Takurō to classical composer and popular essayist Dan Ikuma, praised her work as something entirely different from anything that had been done before (see Take 1999, p. 171). Dan even located Yuming's work in a tradition of modern Japanese vocal music that was constructed by and centred around male composers by noting that her songs 'contained a leap from older, overly sentimental songs - one that past Japanese composers ... were unable to achieve' (Dan 1977, p. 4).

This kind of praise is significant in the context of gender, as especially young women have typically not been expected to partake in 'serious' music, which has been presented exclusively as a domain of male artists (Reitsamer 2018, p. 217; Warwick 2007, pp. 2-7). Consequently, the emphasis on masculinity as 'serious' has encouraged women to try to be like men as 'honorary males' rather than negotiate their identities as creative female individuals (Whiteley 2000, p. 76; cf. Ochiai 1996, p. 89). The valuation of masculine over feminine is apparent also in discussion on musical style and sound. Although it would be essentialist to claim any music as 'feminine' based on its composer's gender, musical style and sound are perceived and evaluated in gendered terms (Thompson 2019; Leonard 2007, pp. 96-8). One is typically able to intuitively distinguish between 'feminine' and 'masculine' styles of music; for example, soft and high sounds are characterised as 'feminine' as opposed to powerful and aggressive 'masculine' idioms (Warwick 2007, p. 6).

In this context, it is significant that Japanese female singer-songwriters were recognised as both feminine and artistically serious (compare with Carole King's brand of soft rock; Hoke 1991, p. 269). The origins of New Music are often attributed to Yuming because her musical style was recognised as novel (Ogawa 1988, p. 51). I want to argue that this perceived novelty was, in fact, related to gender. Consider, for

13 Especially Nakajima Miyuki, Itsuwa Mayumi and Taniyama Hiroko have been recognised as pioneering figures. Takeuchi Mariya was even called 'the Saviour' (kyūseishu) of Japanese popular music (Anonymous/Takeuchi 1978, p. 151). For further discussion and examples, see Nagai (2013). 
example, 'Hikōkigumo' (Vapor Trail, 1973) from Yuming's debut album of the same name - a song which is familiar to many for its use in Miyazaki Hayao's animation The Wind Rises (2013). Instead of the masculine electric guitar, the music emphasises the piano and keyboard and Yuming's clear singing voice. However, by drawing from both Procol Harum's 'A Whiter Shade of Pale' and J.S. Bach's Aria from the third orchestral suite in D major (BWV 1068) and by applying unconventional chord progressions in the chorus, the song created an aura of artistic ambition. This kind of seriousness was previously associated virtually solely with male rock and appealed to contemporary audiences and critics alike (Take 1999, p. 171; Bourdaghs 2012, p. 182; Yanagisawa 2011, p. 200). The image of artistic ambition was further enhanced by the lyrics. Instead of describing romance, which had been the most common theme for women singers, 'Hikōkigumo' was a song about death, possibly suicide (Matsutoya 1984, pp. 81-3). However, unlike the relatively straightforward depictions of social issues by male singer-songwriters, Yuming's version was more sophisticated: the lyrics describe a young person climbing up a white slope all the way up to the sky, where her life becomes a 'vapor trail'. In addition, the calm and reassuring atmosphere of the music seems to conflict with the conspicuously serious theme, creating an intriguing contrast open to interpretation (Bourdaghs 2012, pp. 181-2).

'Hikōkigumo' was a significant song in defining Yuming's signature style and setting the standards of women's New Music as a genre that negotiated the boundaries between commercialism and artistic integrity while representing a recognisably feminine idiom. This came to characterise female singer-songwriters in general. Not only the higher singing voices but also the emphasis on the piano, keyboards and acoustic rather than electric guitar differs from more masculine idioms. This concerns also the emphasis on melody and sensitive lyrics. In other words, the valuation of their music bore social significance by acknowledging the genius of female musicians. By establishing their own musical idiom, Yuming and other female singersongwriters succeeded in articulating that women's music was indeed artistic and serious.

\section{Social context of emergence}

Considering the magnitude of the shift described in the previous three items, it was a notably sudden one. The almost simultaneous appearance of dozens of female singer-songwriters during the early 1970s suggests that it cannot be explained as a mere coincidence or attributed solely to the recognition of the skills of certain talented individuals who happened to debut approximately at the same time. Rather, it implies wider social changes.

Bourdieu (1993) has famously described the 'field' (champ) of cultural production in terms that put more emphasis on recognising the rise of a genius in social structures that enable their appearance rather than adhering to objective aesthetic quality embodied in a genius's work. Equally famously, Bourdieu (and other sociologists) has been criticised for being excessively fixed on structures and not considering aesthetic valuation and pleasure related to music (DeNora 2004). Like many others, I advocate recognising both aspects but will in this section focus on the structural ones. As already noted, female singer-songwriters were able to draw a response from a wide audience but that they were able to debut in the first place naturally required structures supportive of their artistry. In Japan of the 1970s, we can 
distinguish two as especially prominent: those taking place in music production and those taking place on a wider societal level.

Let us first approach the matter from the viewpoint of production. In the history of Western popular music, possibilities have been open to creative women especially in contexts actively supporting women's emancipation (Hoke 1991, pp. 278-9; Bayton 1998, p. 190). The concept of female singer-songwriter eventually provided such a context in Japan, especially from the mid-1970s onwards. Before that, however, the production model emphasising musicianship - or in Bordieuan terms, authorship as cultural capital - was a focal factor. More precisely, this pertained to the discourse of authenticity, which formulated with the emergence of political male singer-songwriters of the late 1960s (Azami 2004, pp. 167-9). Although mainstream folk eventually turned openly commercial and arguably conformist, the difference remaining with kayōkyoku was that it still celebrated the creative authorship of the musician (Bourdaghs 2012, pp. 163-94). This paradigm enabled the type of subtly implied subversion embedded in New Music, but even more importantly, the founding of new record companies by male singer-songwriters resulted in the formation of a field in which the celebration of authorship was more relevant than the author's gender. In other words, the rise of New Music was, by extension, enabled by the politically radical movements of the late 1960s. This is highly ironic considering that the subversive movements fiercely opposed any notions of commercialism only a few years before Yuming's debut but it also contextualises New Music and female singer-songwriters in a politically engaged continuum.

Another important structure was formed by music competitions promoting musicianship, of which particularly the Yamaha Popular Song Contest or 'Popcon' is worth mentioning for its national prominence. Popcon, which was organised from 1969 to 1986, presented mostly young amateur performers pursuing a musical career. The winner received a recording contract and was able to enter as Japan's representative in the international World Popular Song Festival (also organised by Yamaha). Thus, Popcon provided a site on which to express one's creativity presumably detached from ideals of female performers imposed by older production models. The significance of the competition for female musicians is reflected in the large number of female singer-songwriters who made their debut in the competition. ${ }^{14}$

However, the existence of structures supportive of musicianship does not necessarily mean equal support to women and men. After all, female creativity has constantly been downplayed based on claims of 'objective musical quality' defined in male-dominated contexts (Reitsamer 2018; Citron 1993). Considering that music does not merely passively reflect society but also 'serves as a public forum within which various models of gender organisation ... are asserted, adopted, contested, and negotiated' (McClary 2002, p. 7), it seems particularly intriguing that the female singer-songwriters' debuts coincided with the rise of discourses pursuing female emancipation. This social context also forms an apparent parallel with similar developments in other parts of the world: several studies suggest that an interplay between music and women's movements fostered the emergence of influential female singer-songwriters in America and Europe in the 1970s. ${ }^{15}$ A development of this kind is naturally always a complex amalgam of various layers of social,

14 These include Kosaka Akiko (1972), Takagi Masa (1973), Taniyama Hiroko (1974), Yagami Junko (1974), Watanabe Machiko (1974) and Nakajima Miyuki (1975), among others.

15 Perone (2006, pp. 39-41), Kutulas (2010), Shumway (2014, pp. 148-50) and Tomatis (2016, pp. 89-90). 
aesthetic, cultural and productional factors. As such, it is best conceptualised as a reciprocal process based on Small's (1998) and McClary's (2002) theories. When music is examined as an act that both constructs and reflects social values, the previous items suggest that the rise of female singer-songwriters embodied women's emancipation in a dynamic interplay with the wider social sphere in Japan.

An interesting question here is the extent to which foreign exemplars informed the images and possibilities for musical activities for Japanese singer-songwriters. After all, it is usually important to female musicians (whether composers or performers) to have an example with whom to identify (Citron 1993, pp. 54-79; Whiteley 2000 , p. 9). Since the histories of popular music represent a masculine story, however, such examples are notably few. In Japan, the first female singer-songwriters naturally constructed a framework on which later female musicians were able to build their careers (Nagai 2013, pp. 5-42). This concerned especially Yuming, whose recognition was apparent in that promising younger female singer-songwriters were typically referred to as 'the second Yuming' or otherwise compared with her. Nevertheless, the question arises: did the first singer-songwriters have an example with which they could identify or did they really 'start from nothing', as popular music histories tend to claim (Take 1999, p. 169)?

Generally, it would be a simplification to view Japanese female singersongwriters as only emulating their foreign counterparts. Popular music in Asia has its own practices and discourses (Weintraub \& Barendregt 2017) and the process of assimilating and rejecting foreign influences, negotiating identities and constructing new meaning in a local context was much more complex than simply adhering to a one-sided stream of direct influences. To examine this matter, let us first consider the views of the singer-songwriters themselves. Many of them have reported that rather than searching for models among female singer-songwriters, they found their inspiration originated from male musicians in Europe and America (e.g. Itsuwa 1978, p. 29; Anonymous/Takeuchi 1979, p. 49; Matsutōya 1984, p. 91). Takeuchi Mariya even wrote the song 'Mājii biito de utawasete' (Make Me Sing in the Mersey Beat, 1984) about her love of the Beatles, whereas Itsuwa Mayumi (1978, p. 47) later reminisced that she did not originally wish for Carole King to perform on her debut album as she felt that King's music was so different from hers. Furthermore, Itsuwa stated her dislike of her record being marketed with King's name (in Anonymous/Itsuwa 1979, p. 214).

Of course, it is perfectly possible that these statements were simply a strategy of insisting on artistic originality - an aspect that, after all, legitimated the very existence of the singer-songwriter. At the same time, however, these comments also demonstrate the female singer-songwriters' wish to negotiate their position as musicians who sought to create something novel and recognisably feminine inspired by foreign (male) musicians. After all, the type of female identification that has been suggested in the lyrics of Yuming and Nakajima (Kikuchi 2008, p. 248; Shimazaki 2006) was unavoidably different from their foreign counterparts: it took place in the context of Japanese discourses of women and femininity and in the Japanese language. In this respect, female singer-songwriters were successful in constructing their images differently from previous female and male musicians, whether Japanese or foreign.

Although Japanese female singer-songwriters possibly did not recognise (or, at least, admit) influence from their foreign counterparts, their production most certainly did. An important exemplar here is, perhaps unsurprisingly, Carole King. For instance, Yuming's producer Murai Kunihiko visited the United States in the 
early 1970s, witnessed the popularity of female singer-songwriters in America and attended King's studio sessions (Matsuki 2016, pp. 104-6). After this, he wanted to make Yuming the 'Japanese Carole King' and produced her debut album (see Chikushi 1984, p. 202). Furthermore, Itsuwa's debut album Shōjo was recorded in the United States, where King, who had been impressed by Itsuwa's demo tape, participated in the recording. That a young Japanese woman had such an influential American musician playing on her debut album was unheard of in Japan and attracted notable media attention (Anonymous/Itsuwa 1979, p. 214), which naturally also contributed to the recognition of the female singer-songwriter as a category.

Thus, it is likely that especially American exemplars did facilitate the recognition of female singer-songwriters in Japan. There was nothing new in such a process; Japan has deliberately consulted other cultures for new cultural capital throughout its history and since the mid-nineteenth century, examples have been sought especially in Europe and the United States (a process described in Starrs 2011). The practices of popular music were largely built on Anglo-American examples; for example, the discourse of singer-songwriters' authenticity and authorship was adopted from America (cf. Bentley 2018). Similarly, the initiative to employ more women in management positions in the Japanese music industry came from foreign record companies in the late 1980s (Igarashi 1999, p. 88). There is also a tendency for Japanese artists to become nationally recognised only after international validation. For example, art music composer Takemitsu Tōru (1930-1996) was famously belittled by older composers and music critics in Japan until Stravinsky praised his work. Therefore, it is only natural that Itsuwa and later Yano received notable media attention and recognition for having recorded their debut albums in America with well-known musicians such as Carole King, David Campbell and Chris Darrow (Itsuwa's album Shöjo), and members of Little Feat (Yano's album JAPANESE GIRL).

With these remarks, I do not intend to undermine the role of the first female singer-songwriters as pioneering figures, nor do I seek to deny the originality of their work. Rather, in my opinion, these observations present an intriguing transnational aspect to the exchange of influences between the Japan and other countries. This may be conceptualised as a process of cultural vernacularisation, or the 'extraction of ideas and practices from the universal sphere ... and their translation into ideas and practices that resonate with the values and ways of doing things in local contexts' (Merry \& Levitt 2017, p. 213). By writing new songs specifically aimed at a Japanese audience, female singer-songwriters maintained a level of distance from their foreign counterparts while still representing the same, internationally recognised category. In other words, regardless of possible exemplars, they were successful in establishing a new tradition of female musicians in Japanese popular music: it was one that bore specific social and musical meaning in its own social context. Through this process, female singer-songwriters in Japan provided an exemplar not only for individual musicians but also for the music industry and society at large.

\section{Position in historiography}

I wish to emphasise again that it is crucial to understand the nexus of the four items presented above as a whole. They are interrelated in demonstrating the social implications embedded in the concept of female singer-songwriters during the 1970s. While the discussion above emphasises their positive valuation in the 1970s, however, this kind of valuation does not necessarily extend to subsequent views. 
Finally, I would briefly like to address their position in music history from the viewpoint of canonisation.

Canonisation has been assessed in relation not only to Western art music but also to other types of music that have their established ways of emphasising influential works and individuals. Regardless of musical style, the categories that make up canons tend to exclude women (e.g. Schmutz 2018; Leonard 2007, pp. 26-30; Citron 1993). Bayton (1998, p. 23), for example, notes how relatively few performers are female. Even these few have often been excluded from music histories, unless they have become recognised as stars. Social structures have typically discouraged women's participation in public music production but as even highly creative women have tended to be excluded from music histories, it is not an adequate explanation of the issue.

This also concerns Japanese music. Star performers, composers, lyricists and producers have been discussed above in relation to authorship and agency in popular music but the same issue concerns other types of musics as well. Female musicians have always existed in Japan, and in certain contexts, they have even had an influential role in music history despite social restrictions yet these roles are typically downplayed in historiography (Coaldrake 1997; Mehl 2012). To overcome the issue, Marcia J. Citron introduces two approaches to canonising women's music. The first, 'mainstreaming', suggests introducing more women to an already existing (maledominated) canon, whereas the second, 'separatism', favours constructing an altogether new canon that does not support patriarchal modes of thought embedded in existing ones. The two approaches are not necessarily exclusive but can be thought of as a continuum (Citron 1993, pp. 219-20).

Whichever viewpoint we adopt, examination of Japanese popular music histories demonstrates that female singer-songwriters are largely canonised music history. While there are also examples of accounts that only mention a few individuals of a star status, a considerable number of histories recognise female singer-songwriters as a distinct group of performers who have significantly impacted Japanese popular music history. ${ }^{16}$ This demonstrates that their negotiation of female agency eventually succeeded in a manner that surpassed their own temporal and musical context.

\section{Conclusion: female singer-songwriters, popular music and gender equality}

The three main points of this essay may be summarised as follows. First, the rise of the female singer-songwriters in the 1970s marked the first time in Japanese popular music that female musicians were widely recognised and valued as creative artists. Both their concrete agency in music production and the positive reception of their work imply a change in value systems concerning gender roles. Second, by initiating a new era in which women's own voices were being heard in Japanese popular music, female singer-songwriters also embodied the wider pursuit for female emancipation at that time. Third, their emergence was indirectly enabled by subversive movements of the previous decade, and later spurred by the consumerist boom and the ideals of a middle-class society in the 1970s, making them a part of a larger continuum of social and musical change. Therefore, although the genre name 'New Music' was coined to refer to the work of singer-songwriters who introduced a new,

16 Maeda and Hirahara (1993, pp. 168-72), Take (1999, pp. 168-80), Kikuchi (2008, pp. 252-3) and Nagai (2013). 
stylish sound to Japanese popular music and embraced commercialism while not compromising artistic originality, I want to argue that the effective 'new-ness' of the genre was ultimately about social change in Japan. As female singer-songwriters conspicuously differed from the previous dominant image of the serious author as a male, the 'new' in New Music may also be conceptualised as the emancipation of women musicians in Japanese popular music. And, as we have seen, this aspect of its newness eventually inspired the audiences, music industry and other musicians alike in a manner that goes well beyond the contexts of authorship and originality in popular music.

As stated in the introduction, however, these observations are above all important for forming an understanding of the macro-level significance of the female singer-songwriters. To point out more detailed aspects of the complex and dynamic interplay between their activities and social developments, these observations call for further analyses of their music, audiences and the extent of women's identification with their work. This also concerns the possible limitations to their impact. Although this essay has focused solely on the social progress that the emergence of female singer-songwriters embodied in the 1970s and demonstrated that they became canonised music history, it is equally important to address the subsequent developments of women's agency in Japanese popular music and society. Despite the popularity of feminism in the 1970s, Japan has later gained adverse attention for gender equality issues. For example, the country scored as the lowest industrial nation in the Global Gender Gap Report of the World Economic Forum for several consecutive years in the 2010s. ${ }^{17}$ At the same time, gender equality in Japan is again becoming an increasingly debated topic.

In the context of promoting female agency today, it is crucial to understand in which kinds of circumstances female agency has thrived before and which kinds it has been diminished. As suggested in this article, the rise of the female singersongwriters required certain social and musical conditions as well as external influence, the convergence of which not only led to music that inspired audiences but also provided exemplars for other female musicians and, by extension, for the Japanese society at large. Understanding the magnitude of the change, as well as its catalysts and subsequent shortcomings, contributes not only to a more profound understanding of music history but also to social change.

\section{References}

Anonymous 1978. 'Nyū myūjikku tettei kenkyū: Futatsu no bun'ya no kurosuōbaa ga hajimatta!', Shūkan heibon, 20/17, pp. 46-51

Anonymous/Itsuwa, M. 1972. 'Ningen hōmon: Itsuwa Mayumi', Music Life, 22/11, pp. 188-9

Anonymous/Itsuwa, M. 1979. 'Itsuwa Mayumi (28) ga kataru kokō no uta, koi, jinsei', Shūkan Myōjō, 22/7, pp. 213-5

Anonymous/Nakajima, M. 1976. 'Nakajima Miyuki no Sapporo: Maiwei jinsei', Shūkan Myōjō, 19/50, pp. 173-5

Anonymous/Nakajima, M. 1978. 'Shōten intabyū: Nakajima Miyuki', Myōjō, 27/2, p. 120

Anonymous/Takeuchi, M. 1978. 'Izumo kara deta ongakukai no kyūseishu: Takeuchi Mariya wa wandā ūman da', Shūkan Myōjō, 21/48, pp. 51-3

Anonymous, Takeuchi, M. 1979. 'Takeuchi Mariya chotto kimamade yasashii ko... ka na', Seventeen, 12/2, pp. 48-9

Anonymous/Takeuchi, M. 1981. 'Takeuchi Mariya ga totsujo kashu kyūgō dengon!: Yamashita Tatsurō to no kekkon de "jijitsujō no intai" to iu koe mo dete...", Shūkan Heibon, 23/36, pp. 143-5

17 Japan's ranking in 2019 was 121; in 2018, it was 110, and in 2017, 114. 
Anonymous/Yagami, J. 1978. 'Yagami Junko no higeinōjinteki hatachi no seishun', Shūkan Myōjō, 21/47, pp. $172-3$

Anonymous/Yagami, J. 1979. 'Yagami no Jun-chan wa kokoro no soko made fudangi datta', Myōjō, 28/2, pp. 88-9

Anonymous/Yano, A. 1977. 'Myūjikku supotto: Yano Akiko', Bungei shunjū, 19/9, p. 51

Aono, M. 1976. 'Nyū myūjikku no kishutachi: Ano hi ni kaeritai kage ga miendai jidai', Sandee Mainichi, 55/10, $123-5$

Aoyagi, H. 2005. Islands of Eight Million Smiles: Idol Performance and Symbolic Production in Contemporary Japan (Cambridge, MA, Harvard University Asia Center)

Azami, T. 2004. Popyurā ongaku wa dare ga tsukuru no ka: Ongaku sangyō no seijigaku (Tokyo, Keisō Shobō)

Bayton, M. 1997. 'Women and the electric Guitar', in Sexing the Groove: Popular Music and Gender, ed. S. Whiteley (London, Routledge), pp. 37-49

Bayton, M. 1998. Frock Rock: Women Performing Popular Music (Oxford, Oxford University Press)

Befu, H. 2001. Hegemony of Homogeneity: An Anthropological Analysis of Nihonjinron (Melbourne, Trans Pacific Press)

Bentley, C. A. 2018. "Poet-composers": art and legitimacy in the singer-songwriter movement', in The Routledge Companion to Popular Music Analysis: Expanding Approaches, ed. C. Scotto, K. Smith and J. Brackett (New York, Routledge), pp. 416-25

Borshuk, M. 2016. "The "professional" singer-songwriter in the 1970s', in The Cambridge Companion to the Singer-Songwriter, ed. K. Williams and J. A. Williams (Cambridge, Cambridge University Press), pp. 89-99

Bourdaghs, M. K. 2012. Sayonara Amerika, Sayonara Nippon: A Geopolitical Prehistory of J-Pop (New York, Columbia University Press)

Bourdieu, P. 1993. 'The field of cultural production, or: the economic world reversed', in The Field of Cultural Production: Essays on Art and Literature, ed. R. Johnson (New York, Columbia University Press), pp. 29-73

Chikushi, T. 1984. 'Wakamonotachi no kamigami: Matsutōya yumi', Asahi Journal, 26/35, pp. 51-5

Citron, M. J. 1993. Gender and the Musical Canon (Cambridge, Cambridge University Press)

Coaldrake, A. K. 1997. Women's giday $\bar{u}$ and the Japanese Theatre Tradition (London, Routledge)

Conti, J. 2016. 'Politique des chant-auteurs: French auteur theory and Italian canzone d'autore compared', in The Singer-Songwriter in Europe: Paradigms, Politics and Place, ed. I. Marc and S. Green (London, Routledge), pp. 37-49

Cope, J. 2007. Japrocksampler: How the Post-war Japanese Blew Their Minds on Rock ' $n$ ' Roll (London, Bloomsbury)

Dan, I. 1977. 'Ii ne ano hito: Matsutōya Yumi', Asahi Shinbun, 11 January (evening print), p. 4

DeNora, T. 2004. 'Historical perspectives in music sociology', Poetics, 32/3, pp. 211-21

Edwards, W. 2014. 'Gender, person, and society', in Gender and Japanese Society: Volume III, ed. D. P. Martinez (London, Routledge), pp. 26-43

Ehara, Y. 1993. 'Japanese feminism in the 1970s and 1980s', U.S.-Japan Women's Journal, 4, 49-69

Holt, F. 2007. Genre in Popular Music (London, The University of Chicago Press)

Frith, S. 1996. Performing Rites: On the Value of Popular Music (Oxford, Oxford University Press)

Greig, C. 1997. 'Female identity and the woman songwriter', in Sexing the Groove, ed. S. Whiteley (London, Routledge), pp. 168-77

Hagita, M. 2018. Hittokyoku no ryōrinin: Henkyokuka Hagita Mitsuo no jidai (Tokyo, Rittor Music)

Hoke, S. K. 1991. 'American popular music', in Women \& Music: A History, ed. K. Pendle (Bloomington, IN, Indiana University Press), pp. 258-81

Igarashi, T. 1999. 'Ongaku sangyō ni okeru josei', in Narihibiku 'sei': Nihon no popyurā ongaku to jendāa, ed. Kitagawa J. (Tokyo, Keisō Shōbō), pp. 84-106

Inamasu, T. 1989. Aidoru kōgaku (Tokyo, Chikuma Shōbō)

Inoue, T. 1981. Joseigaku to sono shūhen (Tokyo, Keisō Shobō)

Inoue, T. 2009. 'Media ga josei wo tsukuru? Josei ga media wo tsukuru?', in Shinpen Nihon no feminizumu 7: Hyōgen to media (Tokyo, Iwanami Shoten), pp. 1-36

Itsuwa, M. 1978. Ugokanai tokei (Tokyo, Daiwa Shobō)

Ivy, M. 1993. 'Formations of mass culture', in Postwar Japan as History, ed. A. Gordon (Berkeley, CA, University of California Press), pp. 239-58

Kamidate, K. 2019. 'Takeuchi Mariya: Watashi wa utaite, motomerareru ongaku, jibun ga tsukuritai ongaku no baransu daiji', Shūkan Asahi, 13 September 2019, pp. 112-5

Kärjä, A. 2006. 'A prescribed alternative mainstream: popular music and canon formation', Popular Music, 25/1, pp. 3-19

Kikuchi, K. 2008. Nihon ryūkōka hensenshi: Kayōkyoku no tanjō kara J-poppu no jidai e (Tokyo, Ronsōsha)

Kuji, T. 1982. 'Ryūkōka no shakaigaku: Hitobito no aikōkyoku no kōsatsu', Mie daigaku kyōiku gakubu kenkyū kiyō, 33, pp. 19-39

Kutulas, J. 2010. “"That's the way I've always heard it should be": baby boomers, 1970s singer-songwriters, and romantic relationships', Journal of American History, 97/3, pp. 682-702

Lankford, R. D. 2010. Women Singer-Songwriters in Rock: A Populist Rebellion in the 1990s (Lanham, MD, Scarecrow Press)

Lehtonen, L. 2019. Japanilainen musiikki: Taiko-rumpujen kuminasta J-poppiin (Helsinki, Gaudeamus) 
Leonard, M. 2007. Gender in the Music Industry: Rock, Discourse and Girl Power (Aldershot, Ashgate)

Mackie, V. 2003. Feminism in Modern Japan: Citizenship, Embodiment and Sexuality (Cambridge, Cambridge University Press)

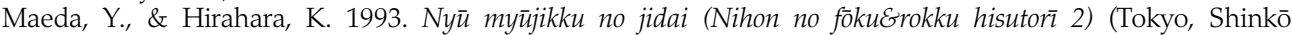
Myūjikku)

Matsuki, N. 2016. 'Arufa no densetsu': Sakkyokuka Murai Kunihiko no jidai (Tokyo, Kawade Shobō Shinsha)

Matsutōya, Y. 1984. Rüju no dengon (Tokyo, Kadokawa Shoten)

McClary, S. 2002. Feminine Endings: Music, Gender, and Sexuality (Minneapolis, MN, University of Minnesota Press)

Mehl, M. 2012. 'A man's job? The Kôda Sisters, violin playing, and gender stereotypes in the introduction of Western music in Japan', Women's History Review, 21/1, pp. 101-20

Merry, S. E. \& Levitt, P. 2017. 'The vernacularization of women's human rights', in Human Rights Futures, ed. S. Hopgood (Cambridge, Cambridge University Press), pp. 213-36

Minamida, K. 2001. Rokku myūjikku no shakaigaku (Tokyo, Seikyūsha)

Minamida, K. 2014. 'The development of Japanese rock: a Bourdiean analysis', in Made in Japan: Studies in popular music, ed. T. Mitsui (New York, Routledge), pp. 120-38

Moore, A. 2002. 'Authenticity as authentication', Popular Music, 21/2, pp. 209-23

Nagahara, H. 2017. Tokyo Boogie-Woogie: Japan's Pop Era and its Discontents (Cambridge, Harvard University Press)

Nagai, H. (ed.) 2013. Nihon no josei shingāa-songuraitā (disuku korekushon) (Tokyo, Shinkō Myūjikku Entateimento)

Negus, K. 2011. 'Authorship and the popular song', Music \& Letters, 92/4, 607-29

Ochiai, E. 1996. The Japanese Family System in Transition: A Sosiological Analysis of Family Change in Postwar Japan (Tokyo, LCTB International Library Foundation)

Ogawa, H. 1988. Ongaku suru shakai (Tokyo, Keisō Shobō)

Okamoto, K. 2015. 'Suburbanization of Tokyo and the daily lives of suburban people', in The Japanese City, ed. P. P. Karan and K. Stapleton (Kentucky, The University Press of Kentucky), pp. 79-105

Perone, J. E. 2006. The Words and Music of Carole King (Westport, CT, Praeger)

Reitsamer, R. 2018. 'Gendered narratives of popular music history and heritage', in The Routledge Companion to Popular Music History and Heritage, ed. S. Baker, C. Strong, L. Istvandity and Z. Cantillon (London, Routledge), pp. 26-35

Sakai, J. 2013. Yūmin no tsumi (Tokyo, Kōdansha)

Satō, Y. 2019. Nippon no uta wa dō kawatta ka: Zōho kaitei (Tokyo, Heibonsha)

Schmutz, V. 2018. 'Cultural Consecration and the Creation of Canons', in The Routledge Companion to Popular Music History and Heritage, ed. S. Baker, C. Strong, L. Istvandity and Z. Cantillon (London, Routledge), pp. 67-75

Sewell, W. H., Jr 1999. 'The Concept(s) of Culture', in Beyond the Cultural Turn: New Directions in the Study of Society and Culture, ed. V. E. Bonnell, L. A. Hunt and R. Biernacki (Berkeley: University of California Press), pp. 35-61

Shigematsu, S. 2005. 'Feminism and media in the late twentieth century: reading the limits of a politics of transgression', in Gendering Modern Japanese History, ed. B. Molony and K. Uno (Cambridge, Harvard University Press), pp. 555-89

Shigematsu, S. 2012. Scream From the Shadows: The Women's Liberation Movement in Japan (Minneapolis, MN University of Minnesota Press)

Shimazaki, K. 2006. 'Yūmin, Miyuki no jidai: Hataraku onna toshite hashiritsuzukeru megamitachi no kiseki to kiseki', Aera, 19/17, p. 86

Shiota, S. 2000. Nihon no shakai seiji to jendā: Danjo byōdō no keizai kiban (Tokyo, Nihon Hyōrōsha)

Shumway, David R. 2014. Rock Star: The Making of Musical Icons from Elvis to Springsteen (Baltimore, MD, Josh Hopkins University Press)

Small, C. 1998. Musicking: The Meanings of Performing and Listening (Hanover, NH, University Press of New England)

Stanlaw, J. 2000. "'Open your file, open your mind": women, english, and changing roles and voices in Japanese popular Music', in Japan Pop! Inside the World of Japanese Popular Culture, ed. T. J. Craig (New York, M. E. Sharpe), pp. 75-100

Starrs, R. 2011. Modernism and Japanese Culture (New York, Palgrave McMillan)

Stevens, C. S. 2008. Japanese Popular Music: Culture, Authenticity, and Power (London, Routledge)

Take, H. 1999. Yomu J-POP 1945-1999: Shiteki zenshi (Tokyo, Tokuma Shoten)

Thompson, M. 2019. 'Gendered Sound', in The Routledge Companion to Sound Studies, ed. M. Bull (London, Routledge), pp. 108-17

Till, R. 2016. 'Singer-songwriter authenticity, the unconscious and emotions (Feat. Adele's "Someone like you" $^{\prime \prime}$ ', in The Cambridge Companion to the Singer-Songwriter, ed. K. Williams and J. A. Williams (Cambridge, Cambridge University Press), pp. 291-304

Tong, K. F. B. 2015. 'A tale of two stars: understanding the establishment of femininity in enka through Misora Hibari and Fuji Keiko', Situations: Cultural Studies in the Asian Context, 8/1, pp. 23-44

Tsurumi, S. 1984. Sengo nihon no taishū bunkashi: 1945-1980nen (Tokyo, Iwanami Shoten) 
Ueno, C. 2009. The Modern Family in Japan: Its Rise and Fall (Melbourne, Trans Pacific Press)

Uno, K. S. 1993. 'The Death of "Good Wife, Wise Mother"?', in Postwar Japan as History, ed. A. Gordon (Berkeley, CA, University of California Press), pp. 293-322

Wajima, Y. 2010. Tsukurareta 'Nihon no kokoro' shinwa: 'Enka' wo meguru sengo taishū ongakushi (Tokyo, Kōbunsha)

Warwick, J. 2007. Girl Groups, Girl Culture: Popular Music and Identity in the 1960s (London, Routledge)

Weintraub, A. N. \& Barendregt, B. (eds.) 2017. Vamping the Stage: Female Voices of Asian Modernities (Honolulu, HI University of Hawai'i Press)

Whiteley, S. 2000. Women and Popular Music: Sexuality, Identity, and Subjectivity (London, Routledge)

Yanagisawa, T. 2011. 'Jidai wo tsukutta onna 1: Matsutōya Yumi - "Yūmin to jiritsu suru josei no seiki"', Bungei shunjū 89/3, 196-212

Yano, C. R. 2002. Tears of Longing: Nostalgia and the Nation in Japanese Popular Song (Cambridge, MA, Harvard University Asia Center)

Yoshida, K. 1977. 'Arai Yumi wo tōshite miru atarashii seikatsu no kachikan: Kakoi no naka no shiawase ga miru yume', Seishōnen mondai, 24/8, 14-20

Zettsu, T. 2002. Dō ni mo tomaranai kayōkyoku: 70nendai no jendā (Tokyo, Shōbunsha)

Zettsu, T. 2005. 'Kayōkyoku ni miru josei no hyōshō: Namae no shigaku to seijigaku', Jendā hakusho, 3, pp. 238-54

\section{Discography}

Arai Yumi, Hikōkigumo. Toshiba EMI, ETP-9083. 1973

Arai Yumi, Misslim. Toshiba EMI, ETP-72001. 1974

Arai Yumi, 'Ano hi ni kaeritai' (single). Toshiba Emi, ETP-20174. 1975

Arai Yumi, 14banme no tsuki: The $14^{\text {th }}$ Moon. Toshiba EMI, ETP-72221. 1976

Chiaki Naomi, 'Rouge', Rouge. Nippon Columbia, PX-7031. 1977

Iruka, 'Nagoriyuki' (single). PANAM, ZP-10. 1975

Itsuwa Mayumi, Shōjo. UMI, SOLL-13-UM. 1972

Nakajima Miyuki, 'Jidai', Watashi no koe ga kikoemasu ka. Canyon Records, AV-9001. 1976

Takeuchi Mariya, Variety. MOON, MOON-28018. 1984

Taniyama Hiroko, Shizuka de ii na - Taniyama Hiroko 15 no sekai. King, SKD-1009. 1972

Yagami Junko, Omoide wa utsukushisugite. Discomate Records, DCF-5010. 1978

Yano Akiko. JAPANESE GIRL. Philips Records, FW-5012. 1976 